\title{
Erratum to: Development and application of a multi-residue method for the determination of 53 pharmaceuticals in water, sediment, and suspended solids using liquid chromatography-tandem mass spectrometry
}

\author{
Yann Aminot ${ }^{1} \cdot$ Xavier Litrico $^{2} \cdot$ Mélodie Chambolle $^{2} \cdot$ Christine Arnaud $^{3}$. \\ Patrick Pardon $^{1} \cdot$ Hélène Budzinski ${ }^{1}$
}

Received: 30 September 2015 / Accepted: 30 September 2015 / Published online: 8 October 2015

(C) Springer-Verlag Berlin Heidelberg 2015

Erratum to: Analytical and Bioanalytical Chemistry

DOI: 10.1007/s00216-015-9017-3

We should like to call your attention to the fact that Hélène Budzinski's name was misspelled in the original publication: it should be Hélène Budzinski.

The online version of the original article can be found at http://dx.doi.org/ 10.1007/s00216-015-9017-3.

Hélène Budzinski

h.budzinski@epoc.u-bordeaux1.fr

1 UMR CNRS 5805 EPOC-LPTC, University of Bordeaux, 33405 Talence, France

2 Agence Régionale de Santé (ARS) Aquitaine, Service Santé Environnement, 103 Bis Rue Belleville, 33000 Bordeaux, France

3 LyRE, Research and Development Center of Lyonnaise des Eaux, 33300 Bordeaux 33300, France 